\title{
The Practice of Religious Tourism among Generation Z's Higher Education Students
}

\author{
Julio García-del Junco ${ }^{1}$, Eva M. Sánchez-Teba ${ }^{2}$ D , Mercedes Rodríguez-Fernández ${ }^{2, *(D)}$ \\ and Irene Gallardo-Sánchez ${ }^{1}$ \\ 1 Business and Marketing Department, University of Seville, 41004 Sevilla, Spain; deljunco@us.es (J.G.-d.J.); \\ irenegallardo@gmail.com (I.G.-S.) \\ 2 Economics and Business Department, University of Malaga, 29016 Málaga, Spain; emsanchezteba@uma.es \\ * Correspondence: mmrodriguez@uma.es
}

Citation: García-del Junco, J.; Sánchez-Teba, E.M.; RodríguezFernández, M.; Gallardo-Sánchez, I. The Practice of Religious Tourism among Generation Z's Higher Education Students. Educ. Sci. 2021, 11, 469. https://doi.org/10.3390/ educsci11090469

Academic Editor: Neil Gordon

Received: 13 July 2021

Accepted: 16 August 2021

Published: 27 August 2021

Publisher's Note: MDPI stays neutral with regard to jurisdictional claims in published maps and institutional affiliations.

Copyright: (c) 2021 by the authors. Licensee MDPI, Basel, Switzerland. This article is an open access article distributed under the terms and conditions of the Creative Commons Attribution (CC BY) license (https:// creativecommons.org/licenses/by/ $4.0 /)$.

\begin{abstract}
The purpose of this paper is to shed light on the possibilities offered by religious tourism according to Generation Z's education in values. Both the theoretical and empirical frameworks of the research have focused on Hofstede's Cultural Model, aiming to predict with a certain level of success the influence of cultural and social values on the consumption of religious tourism by the young age segment of Generation Z. A cross-cultural analysis was performed using exponential sampling (Snowball Sampling). All respondents were higher education students. The surveys were carried out using "Google Forms". The results obtained allow the design of a communication plan for the management of Religious Tourism according to the dimensions of Masculinity-Femininity, Individualism-Collectivism, Distance to Power, Risk Aversion, and Long-term Orientation.
\end{abstract}

Keywords: generation Z; Hofstede; religion; tourism; higher education students; culture; values

\section{Introduction}

According to [1] the word "generation" is defined as a group of people or cohorts who share a range of birth years and experiences as they move together throughout time, influencing and being influenced by various critical factors. In relation to generational studies, there is much research that looks for a set of characteristics and values common to people born around particular dates. A generation is defined by a range of singularities and commonalities shared by those born in those years [2].

Specifically, Generation Z is framed between 1994-2010 and is fundamentally influenced by two historical events, the attacks of 11 September 2001 and the economic crisis that erupted with the fall of Lehman Brothers in 2007; this affected their way of understanding the world, with the emergence of education in values related to the sense of community, the collaborative economy, entrepreneurship based on the sum of many (crowdfunding), and care for the environment. Concepts such as smart cities or the Internet of Things are also very present, as they are the first digital natives and move like fish in water in the digital ecosystem [3].

Ref. [4] establish the differentiation of generations or birth cohorts who share the same and unique understanding due to their shared experience in a similar socio-historical context. Thus, Baby Boomers are born between 1943-1963, Generation X, between 1964-1976, and Millennials between 1983-2003. Lastly, Xennials, born between 1977-1982, are a micro generation between Gen $X$ and Millennials and have characteristics of both. Unless they possess special skills, Baby Boomers and Gen X are not comfortable in their relationship with technology. Millennials and Xennials were born in the Information Communication Technology era and are totally familiar with it.

Generation $Z$ has taken over from the Millennials generation; their age does not exceed 23 years old nowadays, and their number in Spain is 7.8 million and more than 2000 million 
worldwide. They are true digital natives, creative, critical, eager to change the world, and in constant search of authenticity.

The National Society for Prevention of Cruelty to Children (NSPCC) expresses the following as the most frequent reason for youth consultations problems related to mental health: "What we are seeing is a generation of young people who are clearly expressing that they are unhappy with themselves and the situations around them," said Emily Cherry, NSPCC board member [5].

The behavior of young people is a recurring subject of numerous studies that examine the attitudes or interests of this segment of the population in an attempt to predict their buying habits or how they relate to others [6-10].

According to estimates by the WYSE Travel Confederation and the World Tourism Organization, travel by this generation in 2017 accounted for $23 \%$ of all tourism trips worldwide [11,12] and was expected to increase in 2019. The reasons for travelling are very varied: a means of getting out of the virtual world in which the relationships of this generation often move, as the real and virtual worlds are complementary realities for them [13]. Tourism gives them experiences that they can only find in the real world. For them, even more than for others, the world is global and they can come into contact with people from multiple places [14].

Therefore, Generation $\mathrm{Z}$ is one of the age groups most open to travel, and they feel comfortable in multicultural environments $[15,16]$. They use social networks and take into account the opinion of their peers, acquire information about the destination, organize their own trip, and like to interact with the local population [17]. They are also prescribers in family relationships, and have a say in $94 \%$ of purchasing decisions in their immediate environment, which includes travel, according to the study [18]. Research on these young people has also revealed a strong demand for work related travel or internships abroad; furthermore, they are no strangers to solidarity tourism [19].

This paper sheds light on how to present the religious tourism to higher education students of Generation $Z$ who have a specific way of conceiving communication with new media [20], the relationship with the environment, or the way of travelling, matching their education in values with the socio-cultural aspects present in religious tourism.

Hence, this study raises two basic research questions. On the one hand, from a theoretical point of view, we will carry out an in-depth literature review covering the topics of culture, generation $Z$, and religious tourism. On the other hand, from an empirical point of view the objective of the research is to know the cultural and social values in the young people of Generation $\mathrm{Z}$ with a certain level of religious commitment; understanding by commitment that they try to fulfil the exigencies of their religion.

The following sections present a review of the literature on the characteristics and education in values of Generation $\mathrm{Z}$, as well as on the socio-cultural aspects of religious tourism. This is followed by the empirical study based on a virtual questionnaire for the collection of primary data. The following section presents the most significant results of the study and ends with the conclusions, limitations, and future lines of research.

\section{Literature Review}

\subsection{Hofstede's Culture}

Geert Hofstede, born in Haarlem (The Netherlands) in 1928, a Dutch psychologist of great influence worldwide, has carried out numerous studies in different fields, especially in social psychology, intercultural psychology, anthropology, and international management. Specializing in cultural relations between different nations [21], he has made a breakthrough in cross-cultural research [22]. However, [23] point out that there is no lack of work questioning the choice of the most appropriate dimensions to conceptualize and operationalize culture [24-31].

Hofstede defines culture as "the programming of the human mind by which one group of people distinguishes itself from another. Culture is learned from its environment and is always a shared collective phenomenon" [32]. 
Since culture is learned and not inherited, Hofstede (1998) [33] proposes that mental programming should be differentiated from human nature and the personality of the individual as the former is inherited and the latter is based on traits that are partly inherited with the individual's unique set of genes and partly learned, as shown in Figure 1 (personality in level 1, culture in level 2, and human nature in level 3).

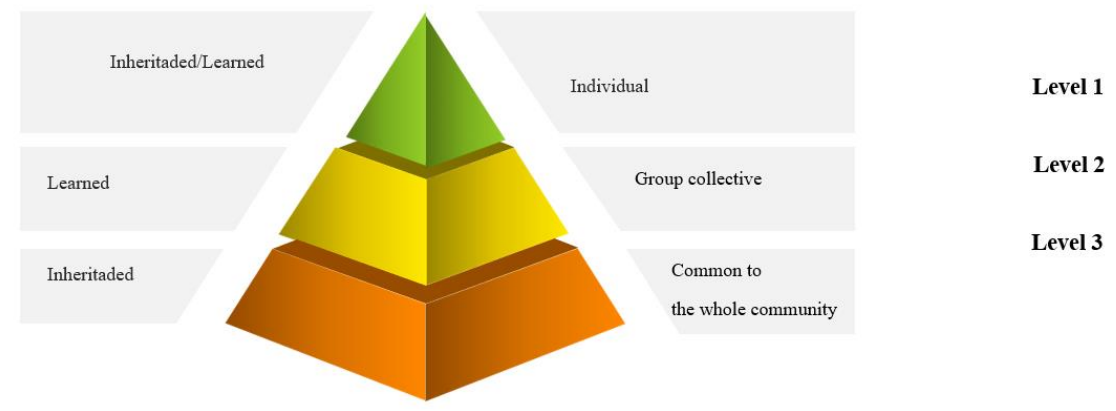

Figure 1. Hofstede's mental programming. Source: Adapted from [34].

Hofstede also suggests that the elements that constitute what we call culture are grouped in several layers. Each layer depends on or is the result of the layer of the lower level as seen in Figure 2.

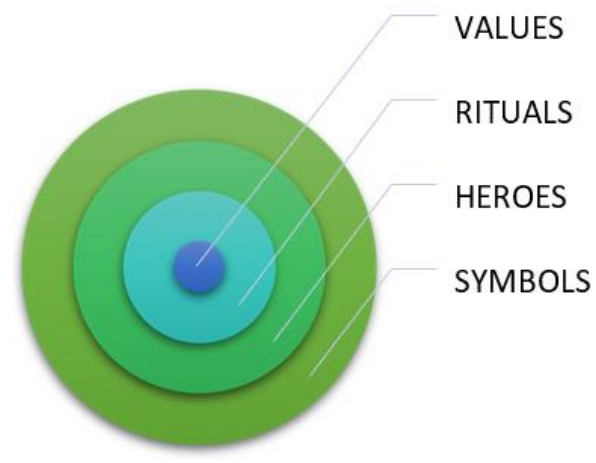

Figure 2. Dimensions of culture according to Hofstede. Source: Adapted from [34].

In the outer layer are symbols, which are images, gestures, words, or objects that have a special meaning that is only distinguished by those who share the culture. In the next layer are heroes, who are people, living or dead, real or imagined, who possess qualities highly valued in a culture and serve as role models. In the layer closest to the nucleus, rituals appear, collective tasks that are technically unnecessary for the achievement of the desired goal, but that within a culture are considered socially primordial, therefore, they are carried out by themselves. The nucleus is formed by the values that refer to the tendencies of individuals to prefer certain states of things to others. They are the essential and constitutive element of culture; enduring beliefs, shared by a group of individuals.

The comparative study of cultures (cross-cultural) is not something new, however, it is from the 1980s when the interest of researchers in this field grew. Thus, in the 1980s and in the 1990s, two rigorous models were developed, that of Hofstede and that of Schwartz. Both models can be used in international management studies, since they are the starting point to understand the different strata of culture [31], with Hofstede's model being considered the cornerstone around which the vast majority of multicultural research work carried out revolves [22]. Soares, Farhangmerh and Shoham (2007) [23], show a comparative synthesis of the Hofstede dimensions approach with other approaches to deconstruct the concept of culture, in which they demonstrate a high level of convergence with other paradigms, thus supporting the theory of Hofstede's frame membership, and later the use of its dimensions being justified. 
According to [27] "cultural dimensions are those characteristic aspects of a culture that can be measured in relation to others", carrying out a study with some 117,000 IBM workers in 66 countries between 1967 and 1973; From this work, he was analyzing the cultural differences between these countries, finally managing to identify four of their six current dimensions: distance to power, individualism/collectivism, masculinity/femininity, and aversion to uncertainty. This first investigation gave rise to the work Culture's Consequences [21].

In a later work, Hofstede (1991) [27] introduces a fifth dimension, resulting from the extension of his study on cultural dimensions to the Asian scene. It was called "longterm/short-term orientation" or "Confucian dynamism."

Finally, it is in his book Cultures and Organizations: Software of the Mind, where he already covers its six cultural dimensions (the sixth being the so-called "indulgence/containment"), where he presents the result of an investigation in which he increased the number of countries to almost double than in the first study [34]. As a consequence, Hofstede's cultural model is interpreted as an expression of education in values globally considered.

According to Hofstede (2011) [35] the distance to power expresses the degree to which less powerful members accept and expect power to be unequally distributed. This distance exists in some way in all human societies, but in some the inequalities are greater than in others, which affects various areas (wealth, prestige, power, etc.), which creates hierarchies between social classes, as well as differences in the family itself.

This dimension, which is also called hierarchical distance, revolves around how societies respond to inequality. There can be two opposing situations in this dimension as it appears in Table 1.

Table 1. Key difference between societies with low and high distance to power.

\begin{tabular}{cc}
\hline Little Distance to Power & Great Distance to Power \\
\hline Inequity is minimized & Inequity is accepted \\
There is a hierarchy for convenience & There is a hierarchy for necessity \\
Superiors are accessible & Superiors are inaccessible \\
Everyone has the same rights & Those in power have privileges \\
Changes happen through natural evolution & Changes happen through revolutions \\
Subordinates wait to be consulted & Subordinates wait to be told what to do \\
Children are treated as equals & Children learn obedience \\
Student-centered education & Teacher-centered education \\
\hline
\end{tabular}

Source: Own elaboration based on [27].

The individualism versus collectivism dimension refers to the social structure of cultures. According to Hofstede (2011) [35] it measures "the degree to which people in a society are integrated into groups", that is, the fact that there is a structured social framework and, within this, to what extent individuals deal with. There may be two opposing situations in this dimension, as seen in Table 2.

Table 2. Key differences between collectivist and individualistic societies.

\begin{tabular}{cc}
\hline Collectivism & Individualism \\
\hline Focus on "us" & Focus on "me" \\
Relationships are more important than tasks & Emphasis on personal choices \\
Comply with obligations imposed by the group & Fulfill your own obligations \\
Violation of the rules leads to feelings of shame & Violation of the rules leads to feelings of guilt \\
Maintain harmony, avoid direct confrontation & Express your thoughts directly \\
Communication is generally High context & Communication is generally Low context \\
\hline Source: Own elaboration based on [27].
\end{tabular}

In individualistic societies, members tend to make decisions independently and care about themselves and about the achievement of the proposed objectives. However, in collectivist societies, the participants are more tolerant; they think more about the 
objectives of the group as this guarantees the best for the individual, with the group taking responsibility for its members.

The masculinity versus femininity dimension refers to the distribution of values between genders; therefore, it refers to the fact that gender differences between men and women are present in the education in values received by the society. The fact that a society resembles more masculine or feminine characteristics affects different environments, such as family, work, education, politics, religion, and social and personal behavior.

This dimension is closely linked to individualism/collectivism and two opposing situations can occur as we can see in Table 3.

Table 3. Key differences between male and female societies.

\begin{tabular}{cc}
\hline Female Society & Male Society \\
\hline $\begin{array}{c}\text { Minimal differentiation of emotional and social roles } \\
\text { between genders } \\
\text { Focused on quality of life } \\
\text { Balance between family and work } \\
\text { Work to live }\end{array}$ & $\begin{array}{c}\text { Maximum differentiation of emotional and social roles } \\
\text { between genders } \\
\text { Focused on ambition } \\
\text { Slow little things are pretty } \\
\text { Work prevails over family } \\
\text { Live to work }\end{array}$ \\
Conflicts are resolved through compromise and negotiation & $\begin{array}{c}\text { Big and fast things are pretty } \\
\text { Conflicts are resolved allowing the strongest to win }\end{array}$ \\
\hline
\end{tabular}

Source: Own elaboration based on [27].

The aversion to uncertainty dimension measures how a society faces changes, new situations, and uncertainty in general; "to what extent a culture programs its members to feel uncomfortable or comfortable in unstructured situations" [35].

Societies adapt differently to the ambiguities of the future depending on the culture to which they belong. There are two opposing situations as we can see in Table 4 .

Table 4. Key differences between societies with weak and high aversion to uncertainty.

\begin{tabular}{cc}
\hline Weak Aversion to Uncertainty & Strong Aversion to Uncertainty \\
\hline Low stress levels in terms of uncertainty & High stress in terms of uncertainty \\
Uncertainty is part of daily life Things are accepted as they come & Uncertainty in life is a continuous threat and must be fought \\
Self-control, low anxiety & Emotionality, anxiety, neuroticism \\
Differences of opinion are acceptable & There is a need for consensus \\
It's okay to take a chance & There is a need to avoid failure \\
Little need for rules and laws & Great need for rules and laws \\
Teachers can say 'I don't know' & Teachers are supposed to have all the answers \\
\hline
\end{tabular}

Source: Own elaboration based on [27].

The long-term versus short-term orientation dimension, also called Confucian dynamism, measures the values of society towards traditions, immediacy, work and, to a large extent, savings and investment. Two opposing situations may exist in this dimension as shown in Table 5.

Table 5. Key differences between long-term and short-term oriented partnerships.

\begin{tabular}{cc}
\hline Long Term Orientation & Short Term Orientation \\
\hline Perseverance and effort produce results slowly & Effort must produce immediate results \\
It is important to save and take care of resources & There is social pressure to spend more \\
Willingness to postpone one's wishes for a good cause & Immediate earnings are more important than relationships \\
place now & The most important events in life will occur in the future \\
\hline
\end{tabular}

Source: Own elaboration based on [27].

The indulgence versus containment dimension measures the quality of life and the emotional effect, that is, joy. According to Hofstede (2011) [35], an indulgent society is one 
that "allows the relatively free satisfaction of basic and natural human impulses related to enjoying life and having fun." There are two opposing situations that are observed in Table 6.

Table 6. Key differences between forbearance and containment-oriented societies.

\begin{tabular}{|c|c|}
\hline Orientation towards Indulgence & Orientation towards Containment and Restraint \\
\hline Free behavior & Suppressed and regulated behaviors \\
\hline Material rewards are not important & Expected material reward for work done \\
\hline Focused on the present moment & You easily feel wronged \\
\hline Material objects are used for their utility, not to give status & Material objects are important to status (car, house, company) \\
\hline People are more positive and optimistic & People are more pessimistic and cynical \\
\hline More outgoing and friendly & Most reserved \\
\hline
\end{tabular}

Source: Own elaboration based on [27].

\subsection{Application of the Hofstede Cultural Model to Tourism}

As we have seen, although Hofstede originally used his model of cultural dimensions in a context of work and human resource management, it has subsequently been increasingly used in a greater number of disciplines, including business [36] and marketing [23]. Within tourism management, it has been applied to the purchase decision process in its three stages: before, during, and after the trip [37]. Tourism marketing strategies have been applied to the product as a perceived value and to communication through the use of the e-marketplace, considering the perceived risk of accepting a website [38] and its specific design [39]

Cultures with a high score in distance to power have higher expectations regarding the quality of the services they are going to receive, especially in the treatment or courtesy. This makes their satisfaction less during and after trips relative to those coming from cultures with a low score [37]. In individualistic cultures, individualism is more a matter of self-image, which has to do with satisfaction during and after the trip being greater in individualistic cultures. On the other hand, collectivist cultures tend to travel more in groups [37].

In addition, these collectivist groups present higher innovation ratios, greater Internet penetration, and a greater predisposition towards differentiation and exclusivity. The more efficient the website (speed of delivery, service development, fulfillment of the contracted services, etc.), the greater the user satisfaction. Along the same lines, this type of culture perceives that the uncertainty or risk that internet use entails is less than its potential benefit [38]. At the opposite extreme, collectivist cultures tend to build trust in previous experiences and group opinions [38].

It has been observed that male cultures tend to be more demanding, complain more often, and show less satisfaction regarding the price and quality of the services offered. They also have less loyalty with the service provider [37]. On the other hand, in female cultures there is greater satisfaction with the service and greater loyalty with the provider [40].

Tourists who score high in the dimension related to aversion to uncertainty have a lower risk threshold and will show behaviors to avoid it to a greater extent than tourists who score low on aversion. Before the trip, risk reduction behaviors include: intensive travel planning, use of travel agencies and tour operators, prepayment of package tours, early booking of accommodation, etc., while during the trip they try to have shorter stays, visiting fewer places on the itinerary, strictly following the planned route, traveling with more money, traveling in a group, etc. [37].

Regarding hotel services, cultures with a high aversion to risk have higher expectations regarding attributes related to food and beverages [40]. In this same sense, this type of culture perceives a greater risk when accepting a website, which makes the perceived usefulness and ease less [38]. At the other extreme, in cultures that score low in risk aversion, users will be more oriented to systems that do not need to deal with another person [39]. 
The long-term versus short-term orientation dimension has great potential for application in tourism research, especially in studies of tourist behavior after the trip. Satisfaction after the trip is conditioned by the tourist's interaction with the tourist service providers. Long-term oriented cultures can show satisfaction after the trip, even if they did not have it during the trip, to protect the relationship with the tourism service provider [37]. In this same sense, with respect to hotel services, this type of culture places great importance on the reliability and knowledge of the service provider, on whom it places higher expectations [40].

Long-term oriented cultures will expect to adopt greater benefits in the future from the use of the Internet and are more likely to adopt this innovation [41]. In the same way, in this type of culture, with respect to the perceived risk on the acceptance of a website, the use they make of it will be greater the more useful it is, since they do not mind investing time in knowing the use of the system [38].

At the opposite pole, short-term-oriented cultures base their attitude towards websites mainly on ease of use [39].

Regarding the long-term versus short-term orientation dimension, no studies related to tourism have been found, possibly because it was the last to be incorporated into the Hofstede Model.

\subsection{Characteristics and Sociocultural Values of Generation $Z$}

Generation Z incorporates everyone born between approximately 1994 and 2010 (there is no exact consensus on the date the cohort began) in a globalized world, where the Internet is the window to the world and smartphones are the most frequent means of communication. They are authentic digital natives [42,43] and they have all the information they need at a mouse or finger click. They use fast messaging, massively social networks, and interactive ICT platforms that allow them to interact and change their purchasing decision process [44]. These characteristics have made this generation one of the most observed and analyzed of all time [45].

Generation $\mathrm{Z}$ is the most ethnically diverse and technologically sophisticated generation with an informal, individual, and direct way of communicating with social media being a vital part of their lives. They are a generation of "do it yourself" [46]. They are more enterprising and tolerant, and more optimistic about their future work since they do not mind working outside their place of origin [47]. It must be taken into account that they have acquired an attention deficit disorder with a high dependence on technology and a low capacity for concentration; it is an individualistic, self-directed, demanding, acquisitive, and materialistic generation [46]. Mihelich (2013) [48] explains that they are young people concerned about social problems such as the environment or inequalities with a high sense of responsibility towards natural resources.

According to Slavin (2015) [49], Generation Z demands to be heard. Technology has been part of their world since they were born, but they lack analytical capacity to solve problems, and it is difficult for them to study the pros and cons of a situation and make a decision [50]. They are used to everything being on the Internet; this group understands that everything can or should be consumed through a network. This shows us young people marked by very clear differentiation features: immediacy and short-termism, innovation and creativity, irreverence and contrast, restlessness and change, and above all sharing; they like to share goods, knowledge, services, and opinions, and they support a collaborative economy. Many businesses of this type have unprecedented success thanks to the support of this generation [3]. This is the result of an education in values received by a segment of young generation who in a few years will become the ones to make the decisions in a globalized world.

\subsection{Religious Tourism Values}

Values can traditionally be defined as "an organized set of preferential norms that are used to make selections of objects and actions, resolve conflicts, invoke social sanctions, 
and address the needs or claims of social and psychological defenses of the choice made or proposed" [51]. Tsang (2011) [52] explains in his work how values affect the attitudes and behaviors of employees at work and in the provision of services. The five factors he determined are attitude toward work, attitude toward people, moral discipline, status and relationships, and moderation. All of them are the result of education in values received by youth.

Values can also be considered as the cognitive representation of an individual for biological needs, social interaction requirements, and social institutional demands [53]. We deduce from the above, and regardless of the various definitions, that values can be used effectively to explain human behaviors, because people feel comfortable with consistency in behaviors derived from attachment to them.

Compared to attitudes, values emphasize more abstract ideals, so they are more stable and occupy a more central position within a person's cognitive system [54]. Therefore, values determine people's motivations, preferences, and lifestyles [55] and are deeper sources of behavior than attitudes [56]. A study carried out by Jurado-Caraballo and Rodríguez-Fernández, (2021) [57] shows how the Management by Values approach is applicable to religious communities to control the productivity of their work. Modrzejewski, (2021) [57] points to Europe as a depositary and promoter of universal values of Christianity, according to the thinking of John Paul II and [58] to analyze the influence of the type of school on the perception of religious values.

In the context of tourism, many researchers have studied how values influence the behavior of tourists in leisure and travel $[59,60]$. In this sense, the values are also widely used for the segmentation of the tourism market. The list of values approach was adopted to divide the international tourism market into three segments: fun and enjoyment oriented, safety conscious, arts and culture conscious, and environmentally conscious [61].

Similarly, Madrigal and Kahle, (1994) [62] found that tourists can be grouped into different segments based on their value systems. Their values primarily comprise internallyoriented values (personal fulfillment, fun and enjoyment, excitement, accomplishment, warm relationships with others, and self-respect) and outward-oriented values (a sense of belonging, being respected, and security). Focusing on inner recollection, Watkins and Gnoth, (2011) [60] found that personal inner harmony and spirituality are important elements of the analysis.

While the aforementioned list of values focuses on individuals, Dalen (1989) [63] tries to segment tourism markets into levels by identifying four types in the Norwegian population: traditional idealists, modern idealists, traditional materialists, and modern materialists. Different social cultures can generate a variety of values, which are good predictors of tourism behavior [60]. Likewise, the cultural environment where people live will shape their values towards life and the world [64].

Cultural tourism is broadly defined as a concept of the movement of persons outside their usual environment who are motivated to visit cultural tourism attractions, with the aim of satisfying their cultural needs through gathering information and experiences. It entails to a diversity of cultural attractions, both tangible and intangible, with museums often being predominantly visited [65]. Similarly, Heiser (2021) [66] explores the variety of motives for a contemporary pilgrimage, whereby religion is only rarely mentioned explicitly. While pilgrimage was originally a purely religious practice, the connection between pilgrimage and religion is less clear nowadays.

We consider culture a fundamental factor in tourism management decisions. This allows a better segmentation of the market, since the consumption of cultural activities and services has the ability to transmit and communicate a certain cultural meaning. In this line, Paganopoulos (2021) [67] shows how the traditional value of hospitality is being reinvented and reappropriated according to the personalized needs of the market of faith. 


\subsection{Generation $Z$ and Tourism}

Generation $\mathrm{Z}$ is a relatively new entrant to the tourism market, which makes this research relevant and timely. The paucity of academic literature on a generation that is contemporaneously in its highly influential life span and is entering adulthood in an increasingly changing world is an additional argument for conducting this research. A holistic theoretical model is proposed to understand the travel experience of this generation.

As digital natives, they prefer to do their searches on the Internet because of its speed, cost, and independence [68]. They have a clear objective and the diversity of brands within their reach is important, until they are saturated [69]. Their interest in technology, the need for security, wanting to get out of their reality, and the need for usability are the characteristics that according to Wood (2013) [16] differentiate Generation Z as customers.

This generation seeks independence, pursuing happiness through travel [70]. Technology makes it possible for trips to be booked autonomously, quickly, anywhere, taking advantage of last-minute offers [71]. They use word of mouth to find attractive destinations [19] which makes these deals much more effective now [72].

All this must be taken into account in order to understand purchasing behavior in relation to tourism. Tourism consumption decisions are influenced by cohort effects [73]. Generation Z shows high expectations in their travels [14] and their way of doing tourism is not conventional; they look for other accommodation options, their relationship with the environment and with the local population is more intense [74], and travel is a way of breaking with the daily routine [75].

At the same time, cultural content plays a less important role for them compared to previous generations [76]. The growth of this tourism segment is a challenge for tourism professionals and requires a rethinking of tourism models [14]. From the point of view of tourism management, smart shopping is an aspect to take into account, and Generation Z are large users of online applications and online purchases [77].

\section{Empirical Study}

\subsection{Objectives}

The objective of the research is to know the cultural and social values in the young people of Generation $Z$ with a certain level of religious commitment; understanding by that commitment that they try to fulfill the exigencies of their religion. Among the main challenges in achieving this objective, we have faced difficulty of selecting people with the Generation $\mathrm{Z}$ profile who adhere to a religion, that is, who practice a religion as a way of life. A second challenge has been the realization of the field work itself; for this we have used the sampling called Snowball Sampling. A third challenge has been to carry out an exponential sampling with this methodology.

\subsection{Methodology}

The analysis was carried out using a questionnaire to obtain the primary data. The survey was carried out with "Google Forms", a "Google Drive" tool created to carry out surveys and forms from which statistics can be performed. The surveys were answered online, since it is the easiest and fastest way to reach the young people of Generation $Z$, as they are in constant interaction with the digital world [78]. It is important to highlight, in this decision, the confinement situation in which we have found ourselves due to COVID-19 has undoubtedly influenced the method and results [4].

To perform this questionnaire, the Geert Hofstede Dimensions Model was used, since it is the most widely used and globally recognized [79]. Specifically, the one provided free of charge for academic purposes on his website [80] was used, consisting of 28 questions, called "Values Survey Module, version 2013".

In addition, four questions have been added in order to focus the research on religious tourism and with higher education students of religious belief from Generation Z (see Appendix A). All this has resulted in a total of 32 questions of various kinds: open, dichotomous, Likert scale, etc., in addition to our own to know the profile of the respondent. 
A pilot study was carried out to verify its correct operation and understanding. Next, we proceeded to carry out the field work definitively using the non-probabilistic method called Snowball Sampling. This data collection mechanism consists of initially launching the survey to a small number of people requesting that after answering it they send it to others providing the same indications. In summary, the process was: (a) we defined the contact participation strategy; (b) we identified the profile of the group to be studied, in this case Generation Z; (c) we chose the size of the conventional sample; (d) we requested the first contacts; (e) we ensured that the contacts were not close to the initial respondents. We followed an Exponential Sampling, so that each individual invited more than two contacts. All respondents were higher education students.

When the total number of higher education students of Generation $\mathrm{Z}$ reached the number of 50, we stopped accepting surveys in order not to exceed the optimal sample size indicated in "Values Survey Module, version 2013" [81]. In this way, 63 surveys were received. After passing the results to an Excel file and filtering them, we eliminated those where the birth of the respondents was 1995 or earlier and those surveyed without possessing or practicing any religion. The results were then tabulated and calculated according to Hofstede's Five Dimensions (Distance to Power, Masculinity/Femininity, Aversion to Uncertainty, Long-Term/Short-Term Orientation, Indulgence/Containment).

Regarding gender and age, the sample is reflected in Figure 3.

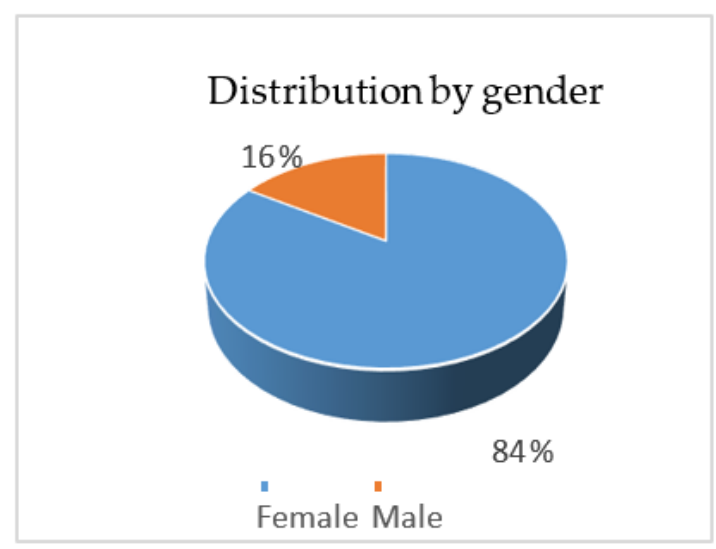

Figure 3. Distribution by gender. Source: Own elaboration.

As can be seen in Figure 4, despite the fact that Generation $\mathrm{Z}$ comprises various ages, $69 \%$ are between 20 and 22 years old. In addition, there is a predominance of women, representing $84 \%$ compared to $16 \%$ representing men.

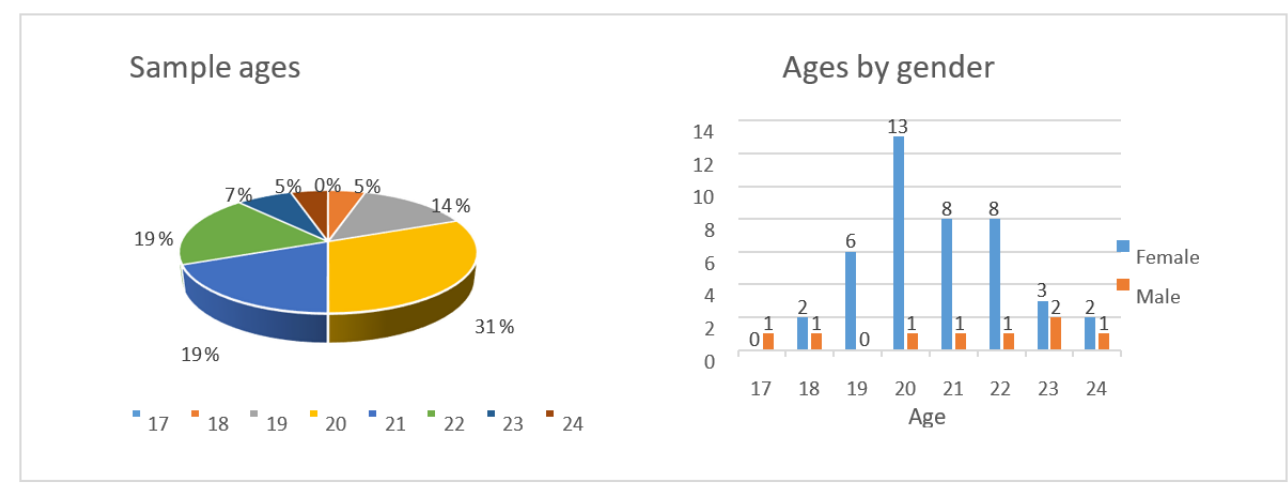

Figure 4. Sample ages and ages by gender. Source: Own elaboration.

On the other hand, in the questions referring to the vision of themself in relation to some religion, they stated that they belong to some religion and that they believe in God. We can see the results in Figure 5. 
Do you consider yourself of any religion?

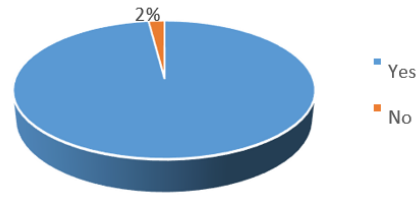

$98 \%$
Do you believe in God?

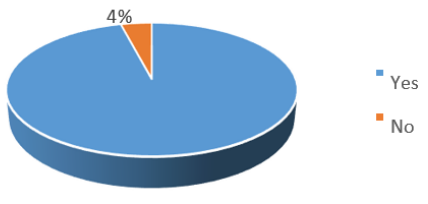

$96 \%$

Figure 5. Religious beliefs of the sample. Source: Own elaboration.

Following the affirmations of belief in God, we observed how individuals live their religion differently, which is manifested in the degree to which they perceive their commitment to it. Although there are different opinions among those surveyed, the majority have determined their level of religiosity as normal-high, as shown in Figure 6. This characteristic has been related to tourism through segmentation based on their motivations to undertake the trip.

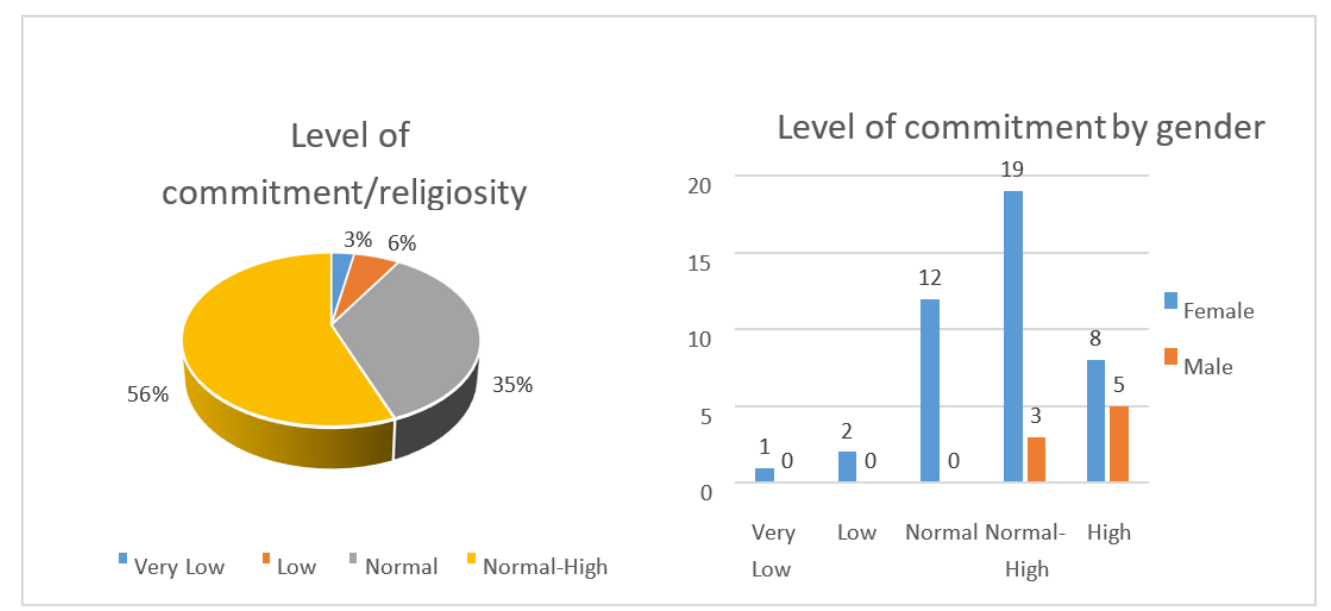

Figure 6. Level of commitment or religiosity. Source: Own elaboration.

As we can see in Figure 7, the men affirmed that they make the trips in a pilgrimtourist modality, as they had indicated in the questionnaire. This circumstance occurs when there is a combination of religious and leisure motives. Most of the women, on the other hand, declared themselves belonging to the group of pilgrims, that is, those who move solely for religious reasons.

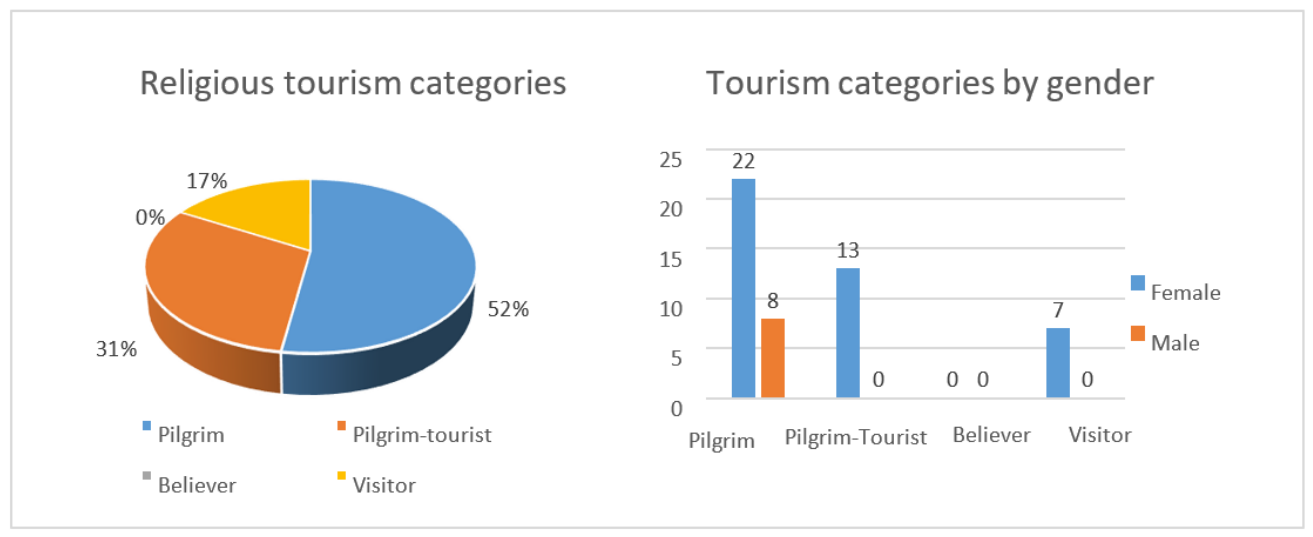

Figure 7. Tourism Categories. Source: Own elaboration. 


\section{Results}

The results obtained for the cultural dimensions are reflected in Figure 8.

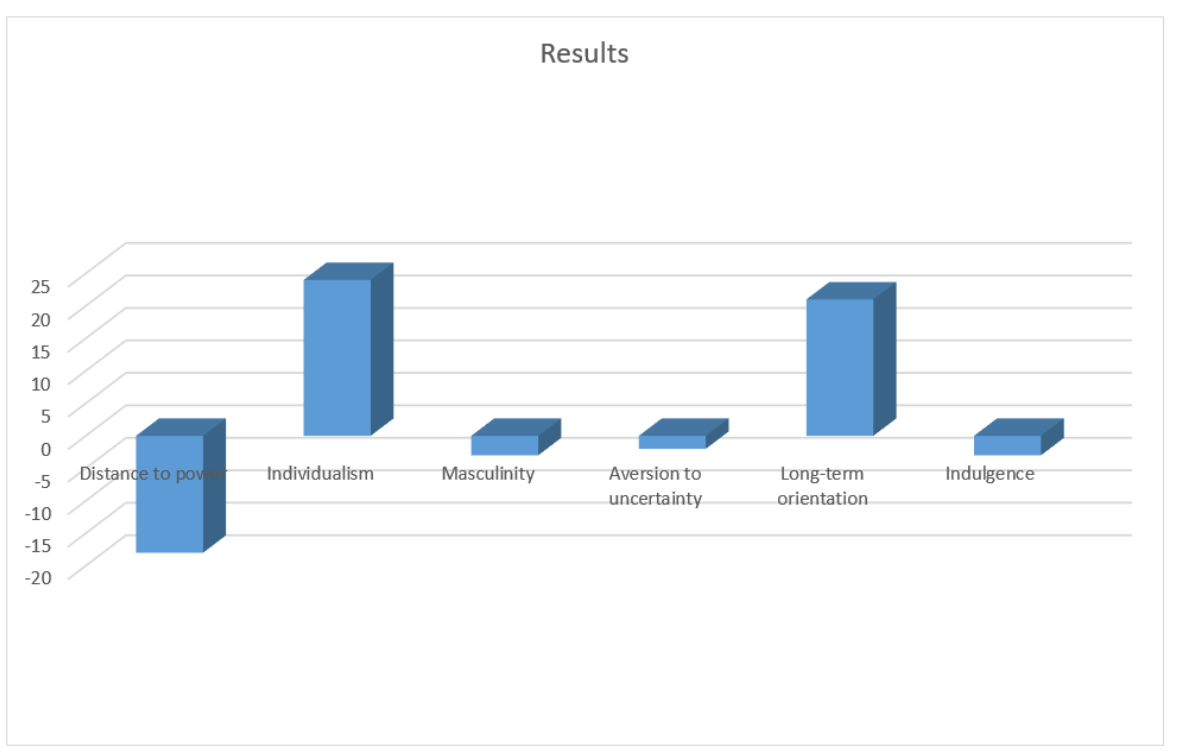

Figure 8. Results of the study. Source: Own elaboration.

As can be seen, there are dimensions that score negatively, a fact that Hofstede himself refers to in some of his publications $[26,27,82]$. Although these values can be passed on a scale from 0 to 100 as reflected in the "Values Survey Module, version 2013", it has been preferred to leave the scores with their sign and not transform them to values between 0 and 100, although technically it is possible that this will better reflect reality [83].

Of the four dimensions with negative values, three of them (Masculinity, Aversion to Uncertainty, and Indulgence) have scores close to 0 , indicating that young people of Generation Z present a high Femininity, Aversion to Uncertainty, and Indulgence. However, the Distance to Power has even lower values. In the two dimensions with positive values, they do not reach the mean value, therefore, the results are of interest because their precision does not allow for wanderings or doubts.

Tsakumis, Curatola and Porcano (2007) [84] investigated the influence of national culture on levels of tax compliance in 50 countries. Using the cultural framework of Hofstede (1980) [21] as the basis for their hypotheses, they found that the profile of a noncompliant country is characterized by high uncertainty avoidance, low individualism, low masculinity, and high power distance. This is the first study to employ Hofstede's cultural framework as explanatory of international tax compliance diversity and serves as a starting point for the development of an international tax compliance framework.

Based on the results obtained, we can establish the following characteristics of the higher education students in the analyzed sample.

In our case, the very low figure obtained $(-18)$ by the individuals surveyed regarding distance to power means that they do not accept an unequal distribution of power and see the hierarchy as something established for convenience, associated with the different functions it performs each person, taking into account that this hierarchy can change. In addition, a low score implies that they consider that superiors should be accessible and that subordinates always expect to be consulted.

In family relationships, they see parents at least as equals and do not believe that they should ask their permission for important decisions [34], unlike Magee and Smith (2013) [85] who proposed in their study the asymmetry in the social distance. Han, Lalwani and Duhachek (2017) [86] examined the relation between power distance belief and the tendency to accept and expect inequalities in society, suggesting that the effect of power distance depends on the power held by the donor. 
The Individualism/Collectivism dimension has been analyzed by authors such as [87] when dealing with the influence of individualism on moral approaches. Zhao and Untea (2017) [88] discuss individualism from the perspectives of Eastern and Western philosophy, approaching a renewed conception of the self and the life of the individual in social relationships that would be closer to a modern understanding of individualism. The analysis of individualism in the USA includes social factors such as growing economic inequality, the complex division between socioeconomic elites and the rest of the population, and changes in the nature of the religious field. The latter include increased religious individualism, an individual-oriented prosperity theology, and a sectarian turn among American evangelicals [89].

Unlike the previous one, this dimension shows positive values [24], these being the highest of all. According to the results, these young people are individualists. Following Hofstede and Minkov (2010) [34], in a pure individualism it would be expected that the ties between individuals are weak and that they only depend on themselves, so they tend to take care only of themselves and the immediate family. From childhood they learn to think in terms of "I". In addition, in this group the right to privacy is invoked, and expressing what one thinks is a sign of honesty.

The Masculinity /Feminity dimension has been studied by Spence (1984) [90], who proposed an alternative theory of self-concepts of masculinity and femininity linked to the concept of gender identity, as opposed to the more familiar concept of sex-role identity. For Hoffman (2001) [91] masculinity and femininity are both psychological and sociocultural constructs that test developers have attempted to assess for many years.

In our research, the results obtained show a high femininity distance; specifically the value obtained was 21 for this group of young people surveyed. As indicated by Hofstede and Minkov (2010) [34], in this case there is a minimal differentiation of emotional and social roles in the genders. There is a balance between work and family because you work to live, looking for a quality of life that allows you to enjoy the small and beautiful things that life gives you. Generation $\mathrm{Z}$ is focused on quality of life; they seek a balance between family life and their external commitments, they think that they work to live, and resolve their conflicts through commitment and negotiation without differentiating by gender. This has recently been corroborated by the study of Garha (2020) [92] applied to Indian communities where male and female roles are approximated given the social and demographic transformation experienced by this population.

Epstein (1999) [93] proposes a definition of uncertainty or aversion to ambiguity. This concept has been reformulated by Andersen et al. (2009) [94], who estimate the extent of uncertainty aversion in a manner that is parsimonious and consistent with theory. They demonstrate that one can jointly estimate attitudes towards uncertainty, attitudes towards risk, and subjective probabilities in a rigorous manner.

The score obtained in this component indicates, according to Hofstede and Minkov (2010) [34], that these young people accept events as they come because uncertainty is part of daily life, which leads them to have self-control, low anxiety, and low levels of stress. They consider that it is okay to take a risk so there is no problem in changing jobs and that differences of opinion are acceptable.

Therefore, the zero aversion to uncertainty of the young people of Generation Z cannot be interpreted only by the generational group to which they belong, but the religious component adds special characteristics, specifically faith, trust in divine providence, the profound meaning of life that illuminates all events, and the conception of eternal life, which more than justify the score obtained in this dimension.

Long-versus short-term orientation was Hofstede's fifth dimension of national cultures [27]. Analyses by Minkov (2007) [95] of World Values Survey data, collected from representative samples of national populations, allowed the calculation of a new version of this dimension, this time across 93 countries. National scores on the dimension correlate with certain family values, school results, business values, environmental values and, under favorable historical conditions, economic growth. The new scores by Hofstede and 
Minkov (2010) [34] allow new predictions for economic developments in different parts of the world.

This magnitude has risen to 21 in the collected questionnaires, and following Hofstede and Minkov (2010) [34], this implies that individuals are oriented towards saving and caring for resources. They believe that perseverance and effort produce results slowly. In turn, they are willing to postpone their own wishes for a good cause.

Tsakumis, Curatola and Porcano (2007) [84] used the Indulgence versus Containment dimension of the Hofstede model, applying it to tax evasion at the level of countries with results of interest. In our case, this dimension has given a negative result for the respondents, specifically a value of -3 . This means, according to Hofstede and Minkov (2010) [34], according to this it would be expected that the young people of Generation Z were oriented towards indulgence, as it happens. In such a culture, behaviors are free, and they have a higher percentage of happy people. In the workplace, material reward does not come first, because material objects are not used to achieve status; consequently, individuals do not feel with easily treated unfairly and people are more positive and optimistic.

This age segment above all values and defends freedom. In this way, we highlight the importance of the practice of religious freedom among young people worldwide [96]. This generation, outgoing and friendly, focuses on the present moment. In addition, they have social concerns and give importance to the well-being of others. That is why we agree with [97] and [98] on the importance of creating the spirit of solidarity among young people in order to improve the world in which we live.

\section{Discussion, Conclusions, Limitations and Future Lines of Research}

After the theoretical review performed, we considered Hofstede's cultural model as the expression of education in values with a global perspective. The profile established for the higher education students belonging to Generation $\mathrm{Z}$ with religious commitment has various implications in the management of religious tourism. From the analysis performed, according to Hofstede's dimensions, and taking into account the results obtained, we characterize Generation $\mathrm{Z}$ according to very specific behavior patterns.

Namely, before the trip, this age segment will not make excessive planning. The journey will tend to be done in a group, and during the trip they will not be excessively demanding, so they will not continually complain about circumstances that arise, although they will value treatment and courtesy received; this will allow them to fully enjoy their trip and in the subsequent outing will tend to do so with the same tourism service provider.

The higher education students of this generation are great innovators and are constantly updated in the field of technology, especially in those who do not need direct contact with another person. For the management of ICTs, they are governed by previous experiences and opinions of the group, mainly those obtained in social networks. They perceive that the risk of using these is always less than the potential benefit, which leads them to make great use of the Internet to reserve or purchase tourist services, but they condition their decisions on the opinion of others. The attitude towards a website will be guided more by its ease of use than by its usefulness and by the reviews of other users who have previously used it.

This directly affects various aspects that should be taken into account when developing an effective management of religious tourism. Thus, companies must rigorously take care of the terms and conditions agreed. An online service must be offered that has a positive impact on the perception of the quality of the service received by customers. It is also important not to save design efforts on the website aimed at reducing user insecurity and dissatisfaction.

Companies that offer religious tourism to higher education students of Generation $\mathrm{Z}$ should invest time to improve the usefulness of the website as it is essential for these users. In this sense, we recommend that they pay maximum attention to online reviews, establishing a job, for example that of a community manager, especially dedicated to answering the assessments made by other people who have previously used the services. 
These responses can be in the form of thanks for the congratulations received, convincing explanations for the complaints made, or apologies in cases where the error is accepted by the tourist service provider.

Another recommendation for these companies is to implement a cross-cultural analysis to carry out a market segmentation based on the results obtained with this study. We believe that it may be of interest for tour operators to specifically reach each market segment if it is previously defined; the management of religious tourism applied to Generation $\mathrm{Z}$ will be more effective if applied in a segmented manner.

In relation to the situation of religious tourism since the pandemic and Generation $\mathrm{Z}$, we can say that there have been many virtual initiatives to participate in events, services, or prayers in the main sanctuaries or holy places. Young people of this generation are very familiar with this environment, so their participation has been easy.

Among the main limitations of this study were the current difficulty for its applicability due to the uncertainty generated in the tourism sector derived from the health crisis caused by COVID-19. We consider that we are at a crucial moment for all types of tourism, and specifically for religious tourism, where the most prudent recommendation is to wait for the situation to return to normal.

Therefore, the future lines of research that we are now considering will be a consequence of the new scenario that tourism will present in the post-COVID-19 era. Although the current situation is not very encouraging, we are convinced that the sector will recover in a short period of time. We believe that religious tourism has an important role and will serve as a foothold in the recovery of the sector, and its practice is not limited exclusively to Generation $\mathrm{Z}$ but to society as a whole.

Author Contributions: Conceptualization, J.G.-d.J., E.M.S.-T. and M.R.-F.; methodology J.G.-d.J. and I.G.-S.; software, I.G.-S.; validation, J.G.-d.J. and I.G.-S.; formal analysis, E.M.S.-T.; investigation, J.G.-d.J. and M.R.-F.; resources, M.R.-F.; data curation, I.G.-S.; writing-original draft preparation, J.G.-d.J., E.M.S.-T. and M.R.-F.; writing-review and editing, M.R.-F. and E.M.S.-T.; visualization, E.M.S.-T.; supervision, J.G.-d.J. and M.R.-F.; project administration, M.R.-F.; funding acquisition, M.R.-F. All authors have read and agreed to the published version of the manuscript.

Funding: The APCs in this article have been funded by MDPI, having been invited to publish in this journal. The publisher's contribution is greatly appreciated by the authors.

Institutional Review Board Statement: Not applicable.

Informed Consent Statement: Not applicable.

Data Availability Statement: Data will be provided by the authors if requested by the readers.

Conflicts of Interest: The authors declare no conflict of interest.

\section{Appendix A}

Indicate which of the following categories of religious tourism you have practiced: Pilgrim: Tourism is carried out solely for religious reasons, being practitioners of a certain religion.

29 Pilgrim-tourist: There is a combination of religious and leisure motifs. Believer: Those who make the journey out of devotion to a particular saint or religious figure without actually practicing a certain religion. Visitor: The reason for your trip is not linked to a religious motive.

\begin{tabular}{cl}
\hline 30 & Do you consider yourself part of any religion? \\
\hline 31 & Believe in God? \\
\hline 32 & $\begin{array}{l}\text { Indicate the level of commitment or religiosity that you think you have with the religion } \\
\text { you profess, with } 1 \text { being a very low commitment and } 5 \text { a high degree of commitment. }\end{array}$ \\
\hline
\end{tabular}




\section{References}

1. Kupperschmidt, B.R. Multigeneration Employees: Strategies for Effective Management. Health Care Manag. 2000, 19, 65-76. [CrossRef] [PubMed]

2. Cogin, J. Are generational differences in work values fact or fiction? Multi-country evidence and implications. Int. J. Hum. Resour. Manag. 2012, 23, 2268-2294. [CrossRef]

3. Injuve. Los Auténticos Nativos Digitales: ¿Estamos Preparados Para la Generación Z? Madrid: Ministerio de Sanidad, Servicios Sociales e Igualdad. 2016. Available online: http:/ / www.publicacionesoficiales.boe.es (accessed on 2 April 2020).

4. Raišienè, A.; Rapuano, V.; Varkulevičiūtè, K. Sensitive Men and Hardy Women: How Do Millennials, Xennials and Gen X Manage to Work from Home? J. Open Innov. Technol. Mark. Complex. 2021, 7, 106. [CrossRef]

5. NSPCC. National Society for Prevention of Cruelty to Children. 2021. Available online: https://www.nspcc.org.uk/ (accessed on 6 April 2020).

6. Roblek, V.; Mesko, M.; Dimovski, V.; Peterlin, J. Smart technologies as social innovation and complex social issues of the Z generation. Kybernetes 2019, 48, 91-107. [CrossRef]

7. Manap, J.; Hamjah, S.H.; Idris, F.; Izani, N.N.M.; Hamzah, M.R.; Malaysia, U.K. Kerelevanan Siaran Radio Terhadap Remaja Generasi Z di Malaysia (The Relevance of Radio Broadcasts Towards Z Generation Teenagers in Malaysia). J. Komunikasi Malays. J. Commun. 2019, 35, 123-142. [CrossRef]

8. Sozbilir, F. Social media, Smart phone and future human resources profile of organizations: Z generations. J. Organ. Behav. Res. 2018, 3, 104-123.

9. Quintanilha, L.F. Inovação pedagógica universitária mediada pelo Facebook e YouTube: Uma experiência de ensino-aprendizagem direcionado à geração-Z. Educ. Rev. 2017, 65, 249-263. [CrossRef]

10. Pérez-Escoda, A.; Castro-Zubizarreta, A.; Igado, M.F. Digital Skills in the Z Generation: Key Questions for a Curricular Introduction in Primary School. Comunicar 2016, 24, 71-79. [CrossRef]

11. WYSE. New Horizons IV: A Global Study of The Youth and Student Traveller; WYSE Travel Confederations: Amsterdam, The Netherlands, 2018.

12. UNWTO. UNWTO Tourism Highlights; World Tourism Organization: Madrid, Spain, 2018.

13. Niemczyk, A.; Seweryn, R.; Smalec, A. Z Generation in the International Tourism Market. Economic and Social Development; Varazdin Development and Entrepreneurship Agency (VADEA): Varazdin, Croatia, 2019; pp. 123-132.

14. Haddouche, H.; Salomone, C. Generation Z and the tourist experience: Tourist stories and use of social networks. J. Tour. Futur. 2018, 4, 69-79. [CrossRef]

15. Törőcsik, M.; Szúcs, K.; Kehl, D. How generations think: Research on generation z. Acta Univ. Sapientiae 2014, 1, 23-45. Available online: https: / / www.ceeol.com/search/article-detail?id=835644 (accessed on 18 April 2020).

16. Wood, S. Generation $\mathrm{Z}$ as consumers: Trends and innovation. Inst. Emerg. Issues 2013, 119, 7767-7779. Available online: https:/ / iei.ncsu.edu/wp-content/uploads/2013/01/GenZConsumers.pdf (accessed on 5 May 2020).

17. Setiawan, B.; Trisdyani, N.L.P.; Adnyana, P.P.; Adnyana, I.N.; Wiweka, K.; Wulandani, H.R. The Profile and Behaviour of ‘Digital Tourists' When Making Decisions Concerning Travelling Case Study: Generation Z in South Jakarta. Adv. Res. 2018, 17, 1-13. [CrossRef]

18. Ipsos. Junior Connect' 2017: Les Jeunes Ont Toujours Une Vie Derrière Les Écrans! 2017. Available online: https:/ /www.ipsos. $\mathrm{com} / \mathrm{fr}$-fr/junior-connect-2017-les-jeunes-ont-toujours-une-vie-derriere-les-ecrans (accessed on 16 May 2020).

19. Mignon, J. Le tourisme des jeunes. Une valeur sure. Cah. Espaces 2003, 77, 1-7.

20. Leonowicz-Bukała, I.; Adamski, A.; Jupowicz-Ginalska, A. Twitter in Marketing Practice of the Religious Media. An Empirical Study on Catholic Weeklies in Poland. Religions 2021, 12, 421. [CrossRef]

21. Hofstede, G. Cultures Consequences: International Differences in Work-Related Values; Sage: Beverly Hills, CA, USA, 1980.

22. Søndergaard, M. Research Note: Hofstede's Consequences: A Study of Reviews, Citations and Replications. Organ. Stud. 1994, 15, 447-456. [CrossRef]

23. Soares, A.M.; Farhangmehr, M.; Shoham, A. Hofstede's dimensions of culture in international marketing studies. J. Bus. Res. 2007, 60, 277-284. [CrossRef]

24. Clark, T. International marketing and national character: A review and proposal for an integrative theory. J. Mark. 1990, 54, 66-79. [CrossRef]

25. Dorfman, P.W.; Howell, J.P. Dimensions of national culture and effective leadership patterns: Hofstede revisited. Advances in International Comparative Management Administrative Science Quarterly. Self or group? Cultural effects of training on self-efficacy and performance. Adm. Sci. Q. 1988, 39, 89-117.

26. Hofstede, G. Cultures Consequences: International Differences in Work-Related Values; Sage: Newbury Park, CA USA, 1984.

27. Hofstede, G.; Hofstede, G.J.; Minkov, M. Cultures and Organizations: Software of the Mind, 3rd ed.; McGraw-Hill: New York, NY, USA, 2010.

28. Keillor, B.; Hult, G. A five-country study of national identity: Implications forinternational marketing research and practice. Int Mark Rev. 1999, 16, 65-82. [CrossRef]

29. Schwartz, S. Beyond Individualism/Collectivism-New Cultural Dimensions of Values. In Individualism and Collectivism-Theory, Method and Applications; Sage Publications: Thousand Oaks, CA, USA, 1994; pp. 85-115.

30. Smith, P.; Dugan, S.; Trompenaars, F. National culture and the values of organizational employees-A dimensional analysis across 43 nations. J. Cross Cult. Psychol. 1996, 27, 231-264. [CrossRef] 
31. Steenkamp, J.E.M. The role of national culture in international marketing research. Int. Mark. Rev. 2001, 18, 30-44. [CrossRef]

32. Hofstede, G.; McCrae, R.R. Personality and Culture Revisited: Linking Traits and Dimensions of Culture. Cross Cult. Res. 2004, 38, 52-88. [CrossRef]

33. Hofstede, G. A case for comparing apples with oranges-International differences in values. International. J. Comp. Sociol. 1998, 39, 16-31. [CrossRef]

34. Hofstede, G.; Minkov, M. Long- versus short-term orientation: New perspectives. Asia Pac. Bus. Rev. 2010, 16, 493-504. [CrossRef]

35. Hofstede, G. Dimensionalizing Cultures: The Hofstede Model in Context. Online Read. Psychol. Cult. 2011, 2, 1-26. Available online: http:/ / scholarworks.gvsu.edu/orpc/vol2/issl/ 8 (accessed on 26 June 2020). [CrossRef]

36. Toubes, D.; del Junco, J.; Abe, M. Cross-cultural analysis of Japanese and Mediterranean entrepreneurs during the global economic crisis. J. Int. Glob. Stud. 2019, 10. Available online: http://www.investigo.biblioteca.uvigo.es/xmlui/handle/11093/2042 (accessed on 6 July 2020).

37. Manrai, L.; Manrai, A. Hofstede's Cultural Dimensions and Tourist Behaviors: A Review and Conceptual Framework. J. Econ. Financ. Adm. Sci. 2011, 16, 23. Available online: https://papers.ssrn.com/sol3/papers.cfm?abstract_id=1962711 (accessed on 4 June 2020).

38. Alcántara-Pilar, J.M.; Barrio-García, S. El efecto del marco cultural del idioma sobre el modelo de aceptación de la tecnología. In Proceedings of the XXII Jornadas Luso-Españolas de Gestión Científica: “Sociedad, territorios y organizaciones: Inclusiones y competitividad", Vila Real, Portugal, 1-3 February 2012; pp. 1-6.

39. Alcántara-Pilar, J.M.; Del Barrio-García, S. El papel moderador del diseño web y la cultura del país en la respuesta del consumidor online. Una aplicación a los destinos turísticos. Eur. Res. Manag. Bus. Econ. 2016, 22, 78-87. [CrossRef]

40. García Sanchis, M.; Gil Saura, I. Expectations, Satisfaction and Loyalty in Hotel Services. A Focus on National Culture. Pap. De Tur. 2015, 37, 7-25. Available online: https:/ / www.cabdirect.org/cabdirect/abstract/20063127545 (accessed on 9 July 2020 ).

41. Sabiote, C. Valor Percibido Global del Proceso de Decisión de Compra Online de un Producto Turístico Efecto Moderador de c Ompra (Tesis Doctoral); Universidad de Granada: Granada, Spain, 2010.

42. MacKenzie, J.; McGuire, R.; Hartwel, S. The First Generation of the Twenty-First Century. 2012. Available online: http: //magid.com/sites/default/files/pdf/MagidPluralistGenerationWhitepaper.pdf (accessed on 25 June 2020).

43. Williams, A. Move Over, Millennials, Here Comes Generation Z. 2015. Available online: https://www.nytimes.com/2015/09/20 / fashion/move-over-millennials-here-comes-generation-z.html?_r\%040 (accessed on 27 August 2020).

44. Stokes, R. eMarketing: The Essential Guide to Marketing in a Digital World. Quirk Education: Cape Town, South Africa, 2013.

45. McCrindle, M.; Wolfinger, E. The ABC of XYZ: Understanding the Global Generations; UNSW Press: Sydney, Australian, 2009.

46. Agarwal, H.; Vaghela, P. Work Values of Gen Z: Bridging the Gap to the Next Generation. In Proceedings of the INC- On 21st and 22nd December 2018-National Conference on Innovative Business Management, Gujarat, India; 2018; pp. 21-22.

47. Schawbel, D. Gen Z Employees: The 5 Attributes You Need to Know. 2014. Available online: http:/ / www.entrepreneur.com/ article/236560 (accessed on 22 July 2020).

48. Mihelich, M. Another generation rises. Workforce Manag. 2013, 92, 34-38.

49. Slavin, A. Marketers: Forget about Millennials. Gen Z Has Arrived. 2015. Available online: http://women2.com/2015/08/07 / engage-gen-z-users / ?hvid=5LyrgK (accessed on 5 April 2020).

50. Coombs, J. Generation Z: Why HR Must Be Prepared for Its Arrival. 2013. Available online: https://www.shrm.org/ resourcesandtools/hr-topics/talent-acquisition/pages/prepare-for-generation-z.aspx (accessed on 4 June 2020).

51. Rokeach, M. Some unresolved issues in theories of beliefs, attitudes, and values. Neb. Symp. Motiv. Neb. Symp. Motiv. 1980, 27, 261-304.

52. Tsang, K.F. Dimensions of Chinese culture values in relation to service provision in hospitality and tourism industry. Int. J. Hosp. Manag. 2011, 30, 670-679. [CrossRef]

53. Schwartz, S.H.; Bilsky, W. Toward a universal psychological structure of human values. J. Pers. Soc. Psychol. 1987, 53, 550-562. [CrossRef]

54. Kamakura, W.A.; Novak, T.P. Value-System Segmentation: Exploring the Meaning of LOV. J. Consum. Res. 1992, 19, 119-132. [CrossRef]

55. Hsu, C.H.; Huang, S. Reconfiguring Chinese cultural values and their tourism implications. Tour. Manag. 2016, 54, 230-242. [CrossRef]

56. Fu, X.; Lehto, X.Y.; Cai, L.A. Culture-Based Interpretation of Vacation Consumption. J. China Tour. Res. 2012, 8, 320-333. [CrossRef]

57. Jurado-Caraballo, M.Á.; Rodríguez-Fernández, M. Productivity in religious orders: A management by values applied approach. Heliyon 2021, 7, e06584. [CrossRef] [PubMed]

58. Civico-Ariza, A.C.; Colomo-Magaña, E.C.; Gonzales-García, E.G. Religious Values and Young People: Analysis of the Perception of Students from Secular and Religious Schools (Salesian Pedagogical Model). Religions 2020, 11, 415. [CrossRef]

59. Mehmetoglu, M.; Hines, K.; Graumann, C.; Greibrokk, J. The relationship between personal values and tourism behaviour: A segmentation approach. J. Vacat. Mark. 2010, 16, 17-27. [CrossRef]

60. Watkins, L.J.; Gnoth, J. Japanese Tourism Values. J. Travel Res. 2011, 50, 654-668. [CrossRef]

61. Muller, T.E. Using Personal Values to Define Segments in an International Tourism Market. Int. Mark. Rev. 1991, 8. [CrossRef]

62. Madrigal, R.; Kahle, L.R. Predicting Vacation Activity Preferences on the Basis of Value-System Segmentation. J. Travel Res. 1994, 32, 22-28. [CrossRef] 
63. Dalen, E. Research into values and consumer trends in Norway. Tour. Manag. 1989, 10, 183-186. [CrossRef]

64. Geertz, C. La Interpretación de Las Culturas; Gedisa: Barcelona, Spain, 2000.

65. Richards, G. Cultural Tourism in Europe. 2018. Available online: https:/ / www.wysetc.org/about-us/ (accessed on 22 June 2020).

66. Heiser, P. Pilgrimage and Religion: Pilgrim Religiosity on the Ways of St. James. Religions. 2021, 12, 167. [CrossRef]

67. Paganopoulos, M. Contested Authenticity Anthropological Perspectives of Pilgrimage Tourism on Mount Athos. Religions 2021, 12, 229. [CrossRef]

68. Lipowski, M. The Differences between Generations in Consumer Behavior in the Service Sales Channel. Ann. Univ. Mariae Curie-Skłodowska Sect. H Oeconomia 2017, 51, 159. [CrossRef]

69. Four Hooks. The Generation Guide-Millennials, Gen X, Y, Z and Baby Boomers. 2015. Available online: http:/ / fourhooks.com/ marketing/the-generation-guide-millennials-gen-x-y-Z-and-baby-boomers-art5910718593/ (accessed on 26 August 2020).

70. Ozkan, M.; Solmaz, B. The Changing Face of the Employees-Generation Z and Their Perceptions of Work (A Study Applied to University Students). Procedia Econ. Finance 2015, 26, 476-483. [CrossRef]

71. Wang, D.; Xiang, Z.; Fesenmaier, D.R. Adapting to the mobile world: A model of smartphone use. Ann. Tour. Res. 2014, 48, 11-26. [CrossRef]

72. Gardiner, S.; Grace, D.; King, C. The Generation Effect. J. Travel Res. 2014, 53, 705-720. [CrossRef]

73. Băltescu, C. Elements of torurism consumer behaviour of generation Z. Bull. Transilv. Univ. Bras. 2019, 12, 63-68. [CrossRef]

74. Van De Walle, I. Le tourisme durable, l'idée d'un voyage ideal. Credoc 2011, 244, 1-4.

75. Carù, A.; Cova, B. How to facilitate immersion in a consumption experience: Appropriation operations and service elements. J. Consum. Behav. 2006, 5, 4-14. [CrossRef]

76. Negrușa, A.; Toader, V. Generational differences in the case of film festival attendance. Generational Impact in the Hospitality Industry. In Proceedings of the International Conference Entrepreneurship in the Hospitality Industry, Cluj-Napoca, România, 5-6 October 2018; pp. 1-7.

77. Priporas, C.-V.; Stylos, N.; Fotiadis, A. Generation Z consumers' expectations of interactions in smart retailing: A future agenda. Comput. Hum. Behav. 2017, 77, 374-381. [CrossRef]

78. Niankara, I.; Al Adwan, M.N.; Niankara, A. The Role of Digital Media in Shaping Youth Planetary Health Interests in the Global Economy. J. Open Innov. Technol. Mark. Complex. 2020, 6, 49. [CrossRef]

79. Yacout, O.M.; Hefny, L.I. Use of Hofstede's cultural dimensions, demographics, and information sources as antecedents to cognitive and affective destination image for Egypt. J. Vacat. Mark. 2015, 21, 37-52. [CrossRef]

80. Hofstede, G. Dimensionalizing Cultures: The Hofstede Model in Context. Online Readings in Psychology and Culture. 2011, 2.

81. Hofstede, G. Cujtural constrainsts in manageent theories. Acad. Manag. Exec. 1993, 7, 81-94. [CrossRef]

82. Hofstede, G. Culture's Consequences: Comparing Values, Behaviors, Institutions and Organizations across Nations. Sage Publications: London, UK, 2001.

83. Hofstede, G. Cultural Dimensions. 2003. Available online: www.geert-hofstede.com (accessed on 27 July 2020).

84. Tsakumis, G.T.; Curatola, A.P.; Porcano, T.M. The relation between national cultural dimensions and tax evasion. J. Int. Account. Audit. Tax. 2007, 16, 131-147. [CrossRef]

85. Magee, J.C.; Smith, P. The Social Distance Theory of Power. Pers. Soc. Psychol. Rev. 2013, 17, 158-186. [CrossRef] [PubMed]

86. Han, D.; Lalwani, A.K.; Duhachek, A. Power Distance Belief, Power, and Charitable Giving. J. Consum. Res. 2017, 44, 182-195. [CrossRef]

87. Trothen, T.J. Moral Bioenhancement through An Intersectional Theo-Ethical Lens: Refocusing on Divine Image-Bearing and Interdependence. Religions 2017, 8, 84. [CrossRef]

88. Zhao, S.; Untea, I. Transcendentalism and Chinese Perceptions of Western Individualism and Spirituality. Religious 2017, 8, 159. [CrossRef]

89. Spickard, J.V. Diversity vs. Pluralism: Reflections on the Current Situation in the United States. Religions 2017, 8, 169. [CrossRef]

90. Spence, J.T. Gender identity and its implications for the concepts of masculinity and femininity. Neb. Symp. Motiv. Neb. Symp. Motiv. 1984, 32, 59-95.

91. Hoffman, R.M. The Measurement of Masculinity and Femininity: Historical Perspective and Implications for Counseling. J. Couns. Dev. 2001, 79, 472-485. [CrossRef]

92. Garha, N.S. Masculinity in the Sikh Community in Italy and Spain: Expectations and Challenges. Religions 2020, 11, 76. [CrossRef]

93. Epstein, L.G. A Definition of Uncertainty Aversion. Rev. Econ. Stud. 1999, 66, 579-608. [CrossRef]

94. Andersen, S.; Fountain, J.; Harrison, G.; Rutström, E. Estimating Aversion to Uncertainty. Working Paper. 2009. Available online: https:/ / www.researchgate.net/publication/228949969_Estimating_aversion_to_uncertainty (accessed on 16 August 2021).

95. Minkov, M. What Makes Us Different and Similar: A New Interpretation of the World Values Survey and Other Cross-Cultural Data; Klasika i Stil Publishing House: Sofía, Bulgaria, 2007.

96. Roy, S. Education and Freedom of Religion or Belief in South and South East Asia; Georgetown University: Washington, WA, USA, 2021. Available online: https://berkleycenter.georgetown.edu/publications/education-and-freedom-of-religion-or-belief-insouth-and-southeast-asia (accessed on 16 September 2020).

97. Marshall, K. Development and Religion: A Different Lens on Development Debates. Peabody J. Educ. 2001, 76, 339-375. [CrossRef]

98. Marshall, K.; Keough, L. Mind, Heart and Soul in the Fight Against Poverty. World Bank: Washington, DC, USA, License: CC BY 3.0 IGO. Available online: https:/ / openknowledge.worldbank.org/handle/10986/14927 (accessed on 30 June 2020). 